\title{
Maize yield, biomass and grain quality traits responses to delayed sowing date and genotypes in rain-fed condition
}

\author{
Qingjun Cao', Gang Li*, Fentuan Yang', Xiaoli Jiang', Lamine Diallo², Enping Zhang'2, Fanli Kong1 \\ ${ }^{1}$ Jilin Academy of Agriculture Science/Key Laboratory of Northeast Crop Physiology Ecology and cultivation, Ministry of Agriculture and Rural \\ Affairs of the People's Republic of China, ${ }^{2}$ College of Plant Science, Jilin University, Changchun 130062, P.R China
}

\section{A B S T R A C T}

\begin{abstract}
Delayed sowing (DS) is a critical factor influencing grain yield and quality under climate change. This study was conducted to determine maize grain yield and quality traits responses to DS and varied genotypes in rain-fed condition, northeast of China. Two typical hybrids ZD958 (higher starch type) and LM33 (higher protein type) and three sowing dates: 30 April (DSO) as normal, 10 May (DS10) and 20 May (DS20) were compared. Results demonstrated maize grain yield, biomass, kernel number per square, thousand kernel weight (TKW), grain nutrition yield, $\mathrm{N}$ concentration and grain test weight were significantly reduced by DS. Compared to high protein type LM33, high starch type ZD958 had a higher yield potential and lower yield reduction with delayed sowing. Grain yield loss under DS could be mainly attributed to reduction of the BMP and biomass, thereby leading to the reduction of TKW and kernels number per unit. DS didn't affected grain nutritional content (starch, protein and oil), while significantly reduced grain nutrition yield of starch, oil and protein with delayed sowing. This study suggests that, early sowing should be recommended to the framers and varieties adjustments maybe a possible approach to reduce and compensate for the loss of yield caused by delayed sowing in rain-fed condition under climate change in NCP.
\end{abstract}

Keywords: Delayed sowing date; Rain-fed condition; Maize; Grain quality; Climate change

\section{INTRODUCTION}

Maize (Zea mays L.) is a major cereal crop in many parts of the world and it used as an important source of food, animal feed, fuel and for various industrial raw materials (Li et al., 2017). Maize grain yield and quality are two main factors concerned in maize production because they are closely related to mankind food security and people's dietary health (Ahmed and Fayyazul, 2015). In the past decades, with the improvement of modern breeding technology and integrated management practice level, the yield of maize has been greatly improved (Tao et al., 2014). However, environmental constraints and increased frequencies of extreme weather under global climate change still are the main factors affecting productivity and sustainable development in many regions of the world (Luo et al., 2018), particularly in rain-fed conditions.

As a key factor influencing farming activities, sowing time is highly associated with cereal grain yield and quality around the world (Bajaj et al., 2008; Wang et al., 2018). Previous studies have demonstrated sowing time is closely related to agro-meteorological factors, such as effective accumulated temperature, precipitation photosynthetic active radiation, even nutrient uptake (Gaile 2012; Verma et al., 2012). Therefore, sowing time is an important factor which would affect the grain yield and quality for field crops. As well known, maize grain yield is significantly and positively correlated with dry matter accumulation during post-anthesis stage (Cao et al., 2017; Guo et al., 2017). In turn, delayed planting date beyond an optimum period can result in substantial biomass and yield loss in most cases, due to shorter duration of vegetative and grain filling period (Nielsen et al., 2002). Gaile (2012) reported biomass of the whole maize plant was reduced by $7 \%$ to $12 \%$ when sowing was done 10 days later than the optimum planting date in Latvia under four years experiment. Similar results were also confirmed by Lawogbomo and Remison (2009) in maize and Shah et al., (2017) in cotton. However, the

\footnotetext{
${ }^{*}$ Corresponding author:

Gang Li ${ }^{1}$, Jilin Academy of Agriculture Science/Key Laboratory of Northeast Crop physiology Ecology and Cultivation, Ministry of Agriculture and Rural Affairs of the People's Republic of China. E-mail: laoli201@yeah.net
}

Received: 24 January 2019; Accepted: 02 June 2019 
previous results were not always in consistent and the corn varieties specific variation is exist. Jaliya et al., (2008) reported there was no significant difference in yield and yield parameters between $10^{\text {th }}$ and $20^{\text {th }}$ June sowing dates with quality protein maize variety in Northern Guinea Savanna ecological zone of Nigeria. While Verma et al., (2012) demonstrated winter maize sown at 25 October enhanced grain yield and the growth than early sowing (15 Oct) and later sowing 5 Nov. Guanming et al., (2013) reported full-season hybrid showed a high silage yield with delayed sowing compared with shorter-season hybrid in southern Wisconsin. Therefore, of sowing date and varieties optimum planting date management combined with varieties is benefit for maximizing grain yield, whereas there are seems differences among varieties. Van Roekel and Coulter (2011) demonstrated that yield loss of late planting with a full-season hybrid was associated with a 7 $\%$ decrease in kernel weight and no change in kernels per square meter. Thus, it was important to evaluate possible genotypic differences of yield and yield components in response to varied sowing dates.

Sowing date is also a critical factor affecting crop quality traits (Abdelkader, 2018). Starch is the mainly seed storage reserves in endosperm of cereal seed (Mason and D'Croz-Mason, 2008). For maize plants, the main material metabolism in the later growth of grain filling is the synthesis of starch, protein and fat, while the accumulation of starch in the early grain filling stage is only transitional, for the pre-synthetized starch could be decomposed and utilized as the source of raw materials for the synthesis of protein, fat and other major storage materials (Yan et al., 2014). Therefore, grain qualities are susceptibly affected by meteorological conditions (e.g. rainfall, photosynthetic radiation intensity, temperature and soil moisture) or management practices in grain filling (Shaik et al., 2014). Precious studies demonstrated planting dates usually had a negative effect on maize grain quality with changes of the seed composition by changing the content of starch, oil, protein, mineral elements and other components (Darby and Lauer, 2002). But the results of precious studies are not consistent. Gaile (2012) indicated sowing time d a slight but significant $(p<0.05)$ effect on crude protein, neutral and acid detergent fiber content reduction. Whereas Fabijanac et al., (2006) reported that sowing date did not affect grain yield and protein content in any of the tested hybrids, but all hybrids tended to have slightly, yet significantly lower oil content with delayed sowing date. In addition, sowing date also highly associated with other physiological and chemical characteristics in food grain crops. Costabr et al., (2013) reported sowing date, varieties and seeding rate significantly affected test weight in bread wheat plants, and grain test weight with delayed sowing showed decrease tends under irrigated Mediterranean systems, and the similar result was also found by Ozturk et al., (2010) in Erzurum (Turkey) dryland conditions. And, the changing in grain qualities by delayed sowing date are related to duration of critical periods for growth or crop establishment, especially for grain filling, but also to genetic and the changes of environmental conditions (Jaliya et al., 2008; Wang et al., 2018).

The Northeast China Plain (NCP), which is famous for "Golden corn belt" and which accounts for more than $30 \%$ of total national corn production in China (Chen et al., 2013). Therefore, it is of remarkable significance to keep a steadily and ever-increasing maize production with the increasing population in China. However, the precipitation in the region decreased by $8.1 \mathrm{~mm}$ and mean temperature increased by 0.3 degrees per decade during the maize growing season from 1961 to 2010 (Liu et al., 2018). The impact of climate variation caused unexpected drought events occurring at maize sowing time have brought many negative impacts on farming operations in this region. In the recent couple of years, field corn planting can be delayed beyond the optimum late April to early May time due to a lack of effective precipitation (Zhao et al., 2018). In turn, the delayed sowing time may affect grain yield stability and quality, and these trends are projected to continue into the future and may bring great risks to food security in this region. But the information about maize yield and quality response to the delayed sowing time and different maize genotypes is till limited. Therefore, our objective of this study was to determine how delayed planting affects yield, yield components and grain quality with different maize genotypes under rain-fed condition in NCP.

\section{MATERIALS AND METHODS}

\section{Site description}

Field experiments were conducted in the central zone of the famous "Golden corn belt" of NCP during two successive maize growing seasons from 2013 to 2014 at Jilin Academy of Agriculture Science experiment station (4320'17'N, $\left.124^{\circ} 20^{\prime} 17^{\prime \prime} \mathrm{E}\right)$ (Fig. 1). This location is considered good representatives of NCP spring maize production areas in terms of soil types, climatic characteristics, geographical distribution, yearly rainfall, and contribution to national maize production. The crop growing season is from April to October, and the averages of 30-year and monthly temperature and precipitation during 2013-2014 of the experiment are given in Table 1. The soil type was loamy clay (FAO, 2006) and its physio-chemical properties in the 0 to $40 \mathrm{~cm}$ soil layer were showed in Table 2 .

\section{Experimental set up and field management}

The experimental was arranged in a randomized complete block in a split plot arrangement with three replications, 


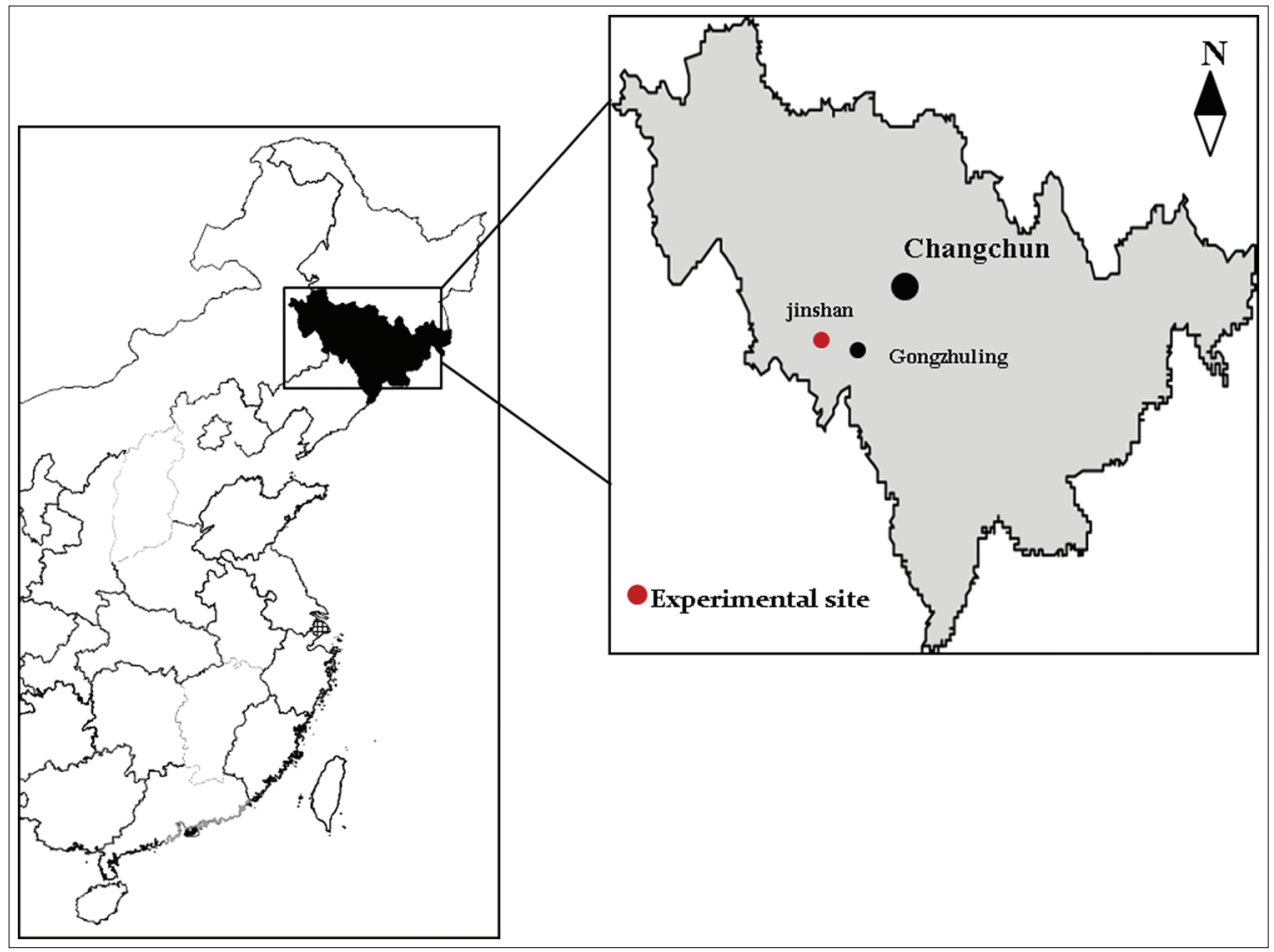

Fig 1. Location of the experimental sites.

Table 1: Monthly temperature and total precipitation during maize growing season of experiment, 2013-2014

\begin{tabular}{|c|c|c|c|c|c|c|c|c|c|c|c|c|}
\hline \multirow[t]{2}{*}{ Month } & \multicolumn{3}{|c|}{ Mean temperature $\left({ }^{\circ} \mathrm{C}\right)$} & \multicolumn{3}{|c|}{ Max temperature $\left({ }^{\circ} \mathrm{C}\right)$} & \multicolumn{3}{|c|}{ Min temperature $\left({ }^{\circ} \mathrm{C}\right)$} & \multicolumn{3}{|c|}{ Total rainfall $(\mathrm{mm})$} \\
\hline & $\begin{array}{c}\text { 30-yr } \\
\text { average }\end{array}$ & 2013 & 2014 & $\begin{array}{c}\text { 30-yr } \\
\text { average }\end{array}$ & 2013 & 2014 & $\begin{array}{c}30-y r \\
\text { average }\end{array}$ & 2013 & 2014 & $\begin{array}{c}30-y r \\
\text { average }\end{array}$ & 2013 & 2014 \\
\hline Apr. & 8.62 & 4.62 & 10.43 & 12.92 & 11.51 & 12.17 & 6.84 & 5.62 & 6.43 & 34.6 & 52.0 & 1.2 \\
\hline May & 17.09 & 18.33 & 16.88 & 21.04 & 22.14 & 22.14 & 11.28 & 11.35 & 11.96 & 49.5 & 23.0 & 98.3 \\
\hline Jun. & 21.87 & 21.64 & 21.40 & 29.02 & 27.65 & 27.65 & 18.32 & 18.62 & 19.14 & 113.55 & 105.6 & 104.8 \\
\hline July. & 23.59 & 24.18 & 23.66 & 28.57 & 28.39 & 28.39 & 21.08 & 20.08 & 20.67 & 143.9 & 119.2 & 58.2 \\
\hline Aug. & 22.83 & 23.18 & 22.45 & 28.67 & 28.92 & 28.92 & 20.56 & 18.57 & 18.95 & 150 & 239.6 & 109.5 \\
\hline Sept. & 17.15 & 17.04 & 17.54 & 23.27 & 23.68 & 23.68 & 10.31 & 10.26 & 9.96 & 40.9 & 21.6 & 46.8 \\
\hline
\end{tabular}

Table 2: Physio-chemical properties of experimental sites before planting in 2013

\begin{tabular}{|c|c|c|c|c|c|c|c|c|c|}
\hline $\begin{array}{l}\mathrm{NaOH} \mathrm{N} \\
\left(\mathrm{mg} \mathrm{kg}^{-1}\right)\end{array}$ & $\begin{array}{l}\text { Olsen-P } \\
\left(\mathrm{mg} \mathrm{kg}^{-1}\right)\end{array}$ & $\begin{array}{c}\mathrm{NH}_{4} \mathrm{OAc}-\text { extracted } \\
\mathrm{K}\left(\mathrm{mg} \mathrm{kg}^{-1}\right)\end{array}$ & Total $\mathbf{N}\left(\mathbf{g ~ k g}^{-1}\right)$ & $\mathrm{pH}$ & $\begin{array}{c}\text { Organic } \\
\text { Carbon (\%) }\end{array}$ & Clay (\%) & Silt (\%) & Sand (\%) & $\begin{array}{l}\text { Bulk density } \\
\left(\mathrm{g} \mathrm{cm}^{-3}\right)\end{array}$ \\
\hline 91.6 & 33.6 & 88.7 & 1.10 & 6.16 & 1.89 & 21.4 & 47.5 & 31.1 & 1.31 \\
\hline
\end{tabular}

where maize genotypes in main plots and three planting dates in sub-plots. Planting dates spaced at about 10-d intervals from 30 April to 20 May in both years, which is referred to as DS0 (control, normal planting date in this area), DS10 (delayed $10 \mathrm{~d}$ ) and DS20 (delayed $20 \mathrm{~d}$ ), respectively.

The plot size was $4.8 \mathrm{~m} \times 10 \mathrm{~m}$ (with 8 rows spaced $60 \mathrm{~cm}$ apart $10 \mathrm{~m}$ long). Two full-seasons of typical commercial hybrids LM33 and DZ958 were choose as the experimental material in the present study. Hybrid maize ZD958 (higher starch maize genotype) was released in 2000 by institute of crop science, Henan Academy of Agricultural Sciences) and LM33 (higher protein maize genotype) was released in 2013 by Songyuan Limin seed co., Ltd, both of which are widely planted in NCP of northeast China (Chen et al., 2013).

The distance between plants in a row was approximately $22.2 \mathrm{~cm}$ and $21.4 \mathrm{~cm}$, with a density of 65,000 plants ha ${ }^{-1}$ (commonly used for maize production in the area). Each plots received a pre-plant basal application of $100 \mathrm{~kg} \mathrm{~N}$ $\mathrm{ha}^{-1}$, 90kg $\mathrm{P}_{2} \mathrm{O}_{5} \mathrm{ha}^{-1}$, and $120 \mathrm{~kg} \mathrm{~K}_{2} \mathrm{O} \mathrm{ha}{ }^{-1}$, respectively, and another $100 \mathrm{~kg} \mathrm{ha}^{-1} \mathrm{~N}$ was sidedressed in top 0 - to $15 \mathrm{~cm}$ soil layer at about $18 \mathrm{~cm}$ away from the rows at V6 stage in both years. Seeds were hand-sown with the aid of a single row hand drill and weeds were controlled using herbicides applied before maize emergence. 


\section{Sampling and determination}

Over the course of the maize growing season, the key phonological phases and total leaf number were recorded at emergence (VE), elongation stage (V6), silking (R1) and physiological maturity stage (R6) according to Ritchie et al (Ritchie and Hanway, 1982).

\section{Biomass, grain yield and yield components determination}

Five adjacent plants samples in each plot were randomly selected and collected at silking and physiological maturity, and divided into grain and all other parts to estimate biomass (above-ground part) and biomass transfer amount. All plant samples were dried at $105^{\circ} \mathrm{C}$ for $30 \mathrm{~min}$ and then at $80^{\circ} \mathrm{C}$ to constant weight. At harvest, $10-\mathrm{m}^{2}$ plant samples at the center of each plot was harvested, the grain yield and yield components was calculated at a moisture content of $14 \%$. Kernel number was determined on 5 randomly selected ears from each plot, and thousand kernel weight (TKW) was determined after maize kernel drying at $80^{\circ} \mathrm{C}$ to a constant weight.

\section{Grain test weight and $\mathbf{N}$ content determination}

Grain test weight was conducted by (Oikeh et al. 1998) method. Grain N content was determined using the Kjeldahl method and followed the description by (Guo et al., 2017), and was determined in accordance with the Risk Assessment Lab of Agri-products Quality and Safety (Changchun), Ministry of Agriculture and Rural Affairs of P.R.C.

\section{Grain starch, oil and protein content determination}

Maize grain starch, protein and oil content in the grain were determined by the method of (Lawogbomo and Remison, 2009) with a near-infrared d reflectance analyzer (Foss infratec TM 1241, Denmark). And grain nutrient yield was performed according to formula (Lawogbomo and Remison, 2009):

Grain nutrient yield $(\mathrm{Mg} / \mathrm{ha})=$ Grain nutrient concentration $\times$ grain yield.

\section{Data Analysis}

All data were analyzed statistically using Microsoft Excel 2010 and SPSS 17.0 software (Inc. Headquarters, Chicago, IL, USA). Probabilities of significance were used to test the significance among treatments (DS and maize genotypes) and their interactions, and Duncan's multiple range test was used to compare the means with treatment of delayed sowing dates $(P<0.05)$.

\section{RESULTS}

\section{Climatic information and phenology}

Sowing date had significant impacts on the timing of key phenological events and variable climatic conditions within a phenological growth stage. In present study, the total rainfall received during growth period was $561 \mathrm{~mm}$ in 2013 and $418.8 \mathrm{~mm}$ in 2014 at experiment site (Table 1), which was slightly higher and lower than normal years (532.45 mm, based on 30-yr average), respectively. The mean temperatures during critical period of maize grain filling periods under timely sown (DS0) and late sown conditions (DS10 and DS20) were 28.32, 27.08 and $25.48^{\circ} \mathrm{C}$ across two years average and total rainfall received during growth period were $24.35,118.85$ and $85.37 \mathrm{~mm}$ respectively.

Variable temperature range and rainfall amount caused by delayed sowing resulted in significant differences in phenological maize development process and the change of biomass, grain quality, yield and yield components. Earlier sown maize of both maize genetypes needed more days from sowing to emergence was found in this study. Compared with DS0, emergence duration time reduced by 3 and 6 days with delayed sowing treatment of DS10 and DS20, respectively. Vegetative period (from emergence to silking) substantially with delayed sowing reduced by 4 days for DS10 and 8 day for DS20 in 2013, together with 5 days for DS10 and 9 day for DS20 in 2014 (Fig. 1). Similarly, reproductive periods were reduced by 2 days for DS10 and 4 days for DS20, and total life period also were reduced approximately 10 and 16 days, correspondingly.

\section{Grain yield and yield components}

As shown in Table 3, maize grain yield, biomass and yield components were significant $(P<0.05)$ or highly significant $(P<0.01)$ affected by DS, maize genotypes $(G)$, and their interactions $(\mathrm{DS} \times \mathrm{G})$ (Table 3).

DS reduced maize grain yield as a whole, along with the increase of delayed sowing time the grain yield loss were increased. Compared with normal planting treatment (DS0), grain yield of DS20 treatment significantly reduced by $11.82 \%$ in 2013 and $15.06 \%$ in 2014; however, grain yield between DS10 and DS0 were not significant. For different maize genotypes, ZD958 had a higher grain yield, by which achieved $13.65 \mathrm{Mg} \mathrm{ha}^{-1}$ in 2013 and $10.82 \mathrm{Mg} \mathrm{ha}^{-}$ ${ }^{1}$ in 2014, while LM33 by $11.25 \mathrm{Mg} \mathrm{ha}^{-1}$ in 2013 and 9.68 $\mathrm{Mg} \mathrm{ha}{ }^{-1}$ in 2014. And maize grain yield reduced by $8.07 \%$ in 2013 and $11.72 \%$ for 2014 , compared with $15.57 \%$ and $18.39 \%$ for LM33, correspondingly. The result indicated maize variety of high starch type had a higher yield potential and lower yield loss in response to DS in rain-fed condition.

To clarify the reasons of maize grain yield loss caused by DS, we determined characters of yield components. The results showed DS mainly significantly affected maize TKW and kernel number per $\mathrm{m}^{2}$ (Table. 3). Maize variety LM33 had more kernels number per $\mathrm{m}^{2}$ than ZD958, but had a lower TKW in yield components. 
Table 3: Effect of delayed sowing date on spring maize grain yield, biomass and yield components in two cultivars (LM33, ZD958) from 2013 to 2014 under rain-fed conditions

\begin{tabular}{|c|c|c|c|c|c|c|}
\hline Year & Genotype & Delayed sowing & Grain yield (Mg ha-1) & Biomass (Mg ha-1) & Thousand kernel weight (g) & Kernel number (No.m-2) \\
\hline \multirow[t]{6}{*}{2013} & LM33 & DSO & $11.99^{\text {ta }}$ & $24.38^{a}$ & $342.03^{\mathrm{a}}$ & $4511.27^{\mathrm{a}}$ \\
\hline & & DS10 & $11.64^{\mathrm{a}}$ & $23.52^{\mathrm{a}}$ & $330.78^{a}$ & $4518.80^{\mathrm{a}}$ \\
\hline & & DS20 & $10.13^{b}$ & $21.60^{c}$ & $305.01^{b}$ & $4105.43^{b}$ \\
\hline & ZD958 & DSO & $14.08^{\mathrm{a}}$ & $26.67^{a}$ & $325.38^{a}$ & $4267.42^{\mathrm{a}}$ \\
\hline & & DS10 & $13.94^{\mathrm{a}}$ & $26.01^{a}$ & $334.73^{\mathrm{a}}$ & $4068.75^{b}$ \\
\hline & & DS20 & $12.94^{b}$ & $24.40^{\mathrm{b}}$ & $310.70^{b}$ & $3850.84^{c}$ \\
\hline \multirow[t]{6}{*}{2014} & LM33 & DSO & $10.54^{\mathrm{a}}$ & $22.40^{\mathrm{a}}$ & $324.38^{\mathrm{a}}$ & $3799.14^{a}$ \\
\hline & & DS10 & $9.89^{\mathrm{b}}$ & $21.56^{b}$ & $314.73^{b}$ & $3702.66^{a}$ \\
\hline & & DS20 & $8.60^{c}$ & $19.36^{c}$ & $295.37^{c}$ & $3447.61^{b}$ \\
\hline & ZD958 & DSO & $11.38^{a}$ & $23.31^{a}$ & $317.76^{a}$ & $3342.34^{a}$ \\
\hline & & DS10 & $11.04^{\mathrm{a}}$ & $22.07^{\mathrm{a}}$ & $304.79^{b}$ & $3365.01^{\mathrm{a}}$ \\
\hline & & DS20 & $10.05^{b}$ & $20.80^{b}$ & $288.17^{\circ}$ & $3087.17^{b}$ \\
\hline \multicolumn{7}{|c|}{ Source of variation } \\
\hline \multicolumn{3}{|c|}{ Delayed sowing (DS) } & ** & ** & ** & * \\
\hline \multicolumn{3}{|c|}{ Genotype (G) } & ** & ** & $\star *$ & * \\
\hline \multicolumn{3}{|c|}{$\mathrm{DS} \times \mathrm{G}$} & * & * & ns & ns \\
\hline
\end{tabular}

†Different small letters represents statistically significant differences at the $P<0.05$ level by Duncan's test. DS0, DS10 and DS20 were indicated seed planting delayed 0,10 , and 20 days from normal planting time, respectively. ${ }^{*} P<0.05 ;{ }^{*} P<0.01$; ns, not significant.

Biomass, biomass at anthesis (BMA), post-anthesis (BMP) and remobilization amount (BMR)

Similarly to maize grain yield, DS significantly decreased plant biomass of both varieties in two years. Compared to DS0, biomass for LM33 reduced by $11.31 \%$ in 2013 and by $13.60 \%$ in 2014 under DS20 treatment, and reduced by $8.56 \%$ and $10.78 \%$ for ZD958, correspondingly (Table 3 ), these results indicated the magnitude of the change with delayed sowing was less than that of LM33. No significant differences were observed between DS10 and DS0.

In addition, significant differences of BMA, BMP and BMR were found by DS, and BMP was also significantly affected by maize genotypes $(\mathrm{G})$ in present study (Fig 2). BMA was reduced by $9.17 \%$ in 2013 and $13.73 \%$ in 2014 across two corn genotypes average. Similarly, BMR reduced by $5.47 \%$ in 2013 and $13.61 \%$ in 2014; BMP was reduced by $5.96 \%$ in 2013 and $6.78 \%$ in 2014, correspondingly. For genotypes, variety ZD958 had a higher BMP in present study.

\section{Grain starch, protein, oil content and yield}

Maize grain starch, protein, and oil content were significantly $(P<0.01)$ affected by maize genotypes $(G)$, whereas not significant by DS (Table 4). Kernels of variety LM33 had significant higher protein (averaged $11.34 \%$ ) and oil content (averaged $4.22 \%$ ) than hybrids ZD958 (averaged $8.57 \%$ and $4.07 \%$, correspondingly), but had less starch content (averaged $70.13 \%$ for LM33 vs. 72.41 $\%$ for ZD958).

Significant reduction of maize grain starch, protein and oil yield by DS were also observed (Fig. 3). Compared with DS0, starch yield were significant reduced by $5.97 \%$ for DS10 and $16.92 \%$ for DS20, protein yield reduced by
$5.08 \%$ and $12.09 \%$, and oil yield reduced by $7.21 \%$ and $19.48 \%$, correspondingly. For different maize genotypes, ZD958 had a higher grain starch yield and lower protein yield across two years average, while no difference of oil yield was found between two maize genotypes.

\section{Grain test weight and $\mathbf{N}$ content}

Grain test weight and N content were affected by DS and maize genotypes $(G)$ (Table 4). DS significantly reduced maize grain test weight and $\mathrm{N}$ content in present study. Maize variety ZD958 had higher grain test weight while less $\mathrm{N}$ content in kernels. Compared to DS0, grain test weight and $\mathrm{N}$ content of LM33 under DS20 reduced by $4.11 \%$ and $4.95 \%$ combined with two years average, respectively. For ZD958, these markedly decreased by $4.03 \%$ and 9.02 $\%$, respectively, with a higher decrement of $\mathrm{N}$ content than LM33. However, no significant difference between DS10 and DS0.

\section{Correlation analysis}

Correlation analysis demonstrated that maize grain yield with delayed sowing highly significantly $(P<0.01)$ and positively correlated with BMP, total biomass and TKW, together with significantly $(P<0.05)$ positively correlated with kernel number per square and grain test weight (Table 5). Grain test weight significantly positively correlated with BMP, and negatively correlated with grain protein content.

\section{DISCUSSION}

\section{Phenology}

Growing degree days (GDD) and rainfall can be significantly affected by sowing time are the main meteorological factors 


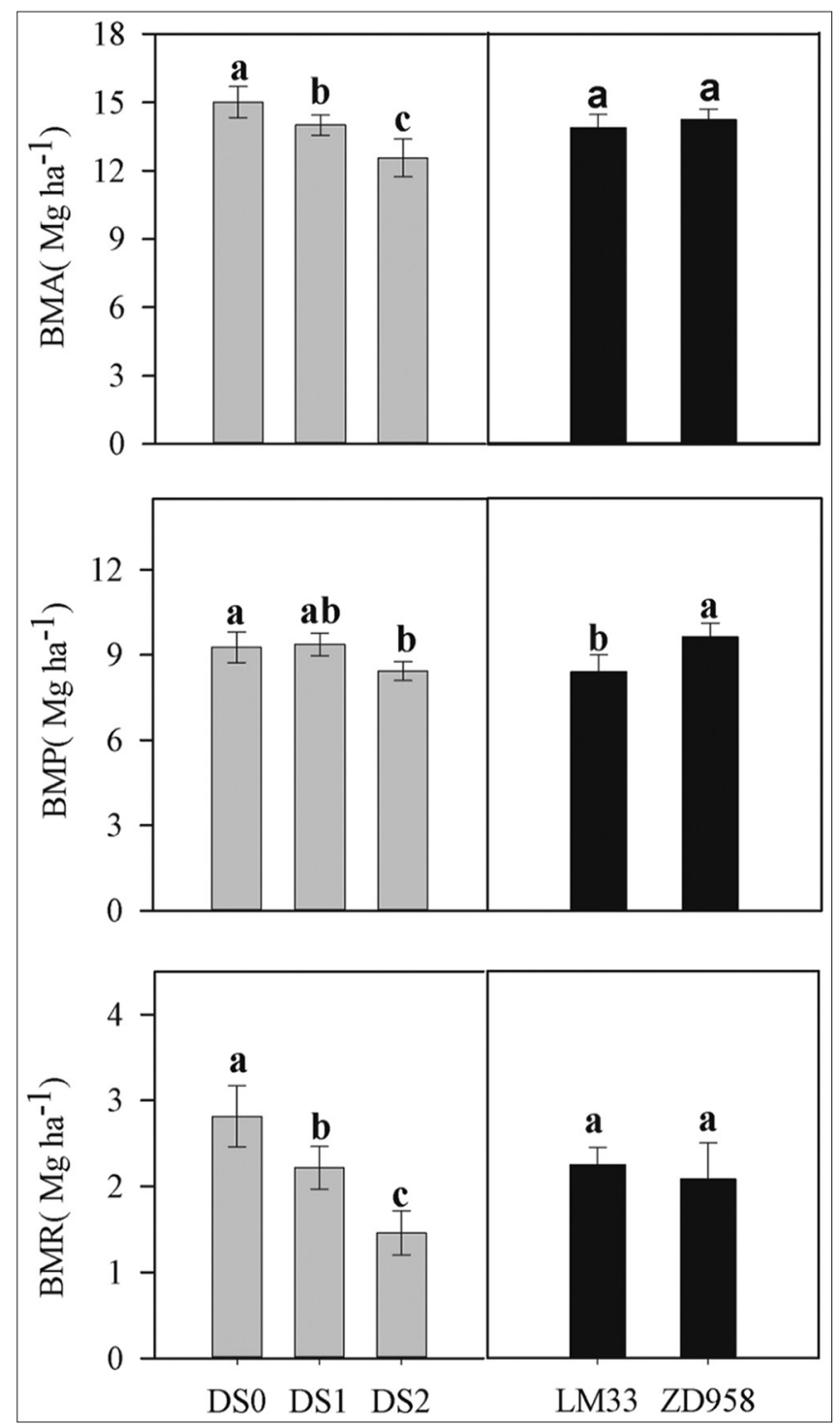

Fig 2. Biomass at anthesis (BMA), post-anthesis (BMP) and remobilization amount (BMR) during grain filling under three delayed planting date (DS0, DS10 and DS20), and in two cultivars (LM33, ZD958) on two years average. Vertical bars represent the means \pm $\mathrm{SD}$. Different letters represents statistically significant differences at the $P<0.05$ level by Duncan's test. DSO, DS10 and DS20 were indicated seed planting delayed 0,10 , and 20 days from normal planting time, respectively.

affecting maize growth and development (Shah et al., 2017; Shirzadi and Madani, 2008). In present study, crop growth and phenological events were significantly affected by delayed planting date. It is well known that soil temperature and moisture are critical factors for a uniformity and quick seed emergence under early spring sowing time. That is the reason why the emergence duration time was reduced 3 and 6 days under delayed planting seeds of DS10 and DS20 treatment, respectively. Our findings are similar to the results that earlier sown maize needed more days till emergence and from emergence till slinking (Gaile, 2012). Photoperiod has been reported as a primary environmental
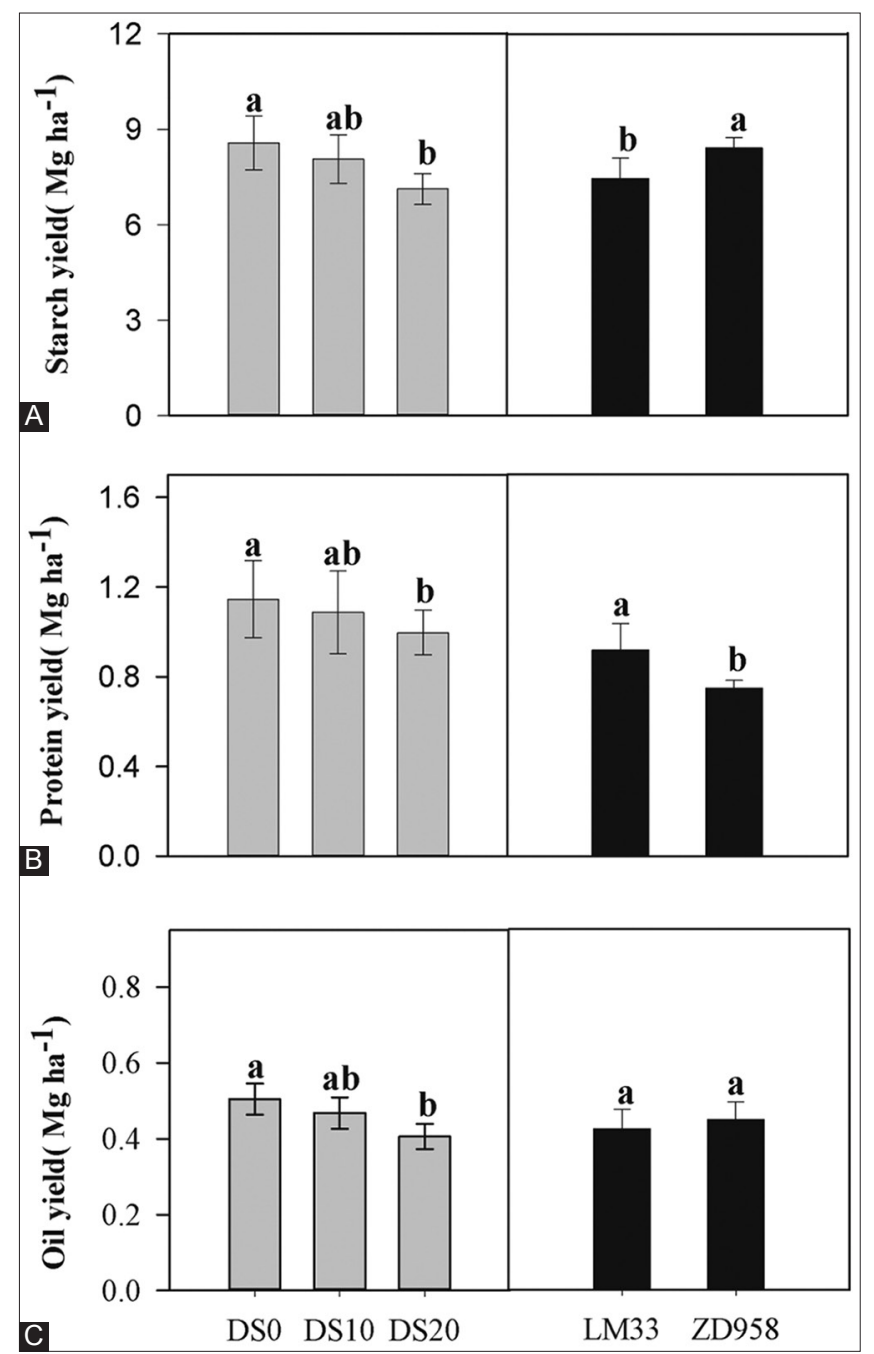

Fig 3. Yield of starch (A), protein (B) and oil (C) under three delayed planting date(DS0,DS10 and DS20) in two years $(2013,2014)$, and in two cultivars (LM33, ZD958). Vertical bars represent the means \pm SD. Different letters represents statistically significant differences at the $P<0.05$ level by Duncan's test. DS0, DS10 and DS20 were indicated seed planting delayed 0,10 , and 20 days from normal planting time, respectively.

factor determining time of flowering and maturity in annual crops, including soybean, rapeseed and maize ( $\mathrm{Li}$ et al., 2015; Shah et al., 2017). In present study, vegetative period (from emergence to silking) and total growth period duration also were both shortened, total period of the life cycle ranged from about $143 \mathrm{~d}$ in the normal sown treatment (DS0) to about 133d for DS10 and 127d for DS20 treatments for both species (Fig. 4). This result was also consistent with that later sowing shortened the total life period of $A$. retroflexus and Chenopodium glaucum (Li et al., 2015).

Grain yield, yield components, BMA, BMP and BMR Increasing food demands by a growing human population require substantial increases in crop productivity in China and other developing counties (Liu et al., 2018). Sowing 
Table 4: Comparison of grain test weight, $\mathrm{N}$ content together with grain starch, protein and oil content under three delayed planting date (DS0, DS10 and DS20) in two years $(2013,2014)$, and in two cultivars (LM33, ZD958)

\begin{tabular}{|c|c|c|c|c|c|c|c|}
\hline Year & Genotype & Delayed sowing & $\begin{array}{c}\text { Grain test weight } \\
\left(\mathrm{g} \mathrm{L}^{-1}\right)\end{array}$ & Grain $\mathrm{N}$ content $(\%)$ & Starch content (\%) & Protein content $(\%)$ & $\begin{array}{c}\text { Oil } \\
\text { content (\%) }\end{array}$ \\
\hline \multirow[t]{6}{*}{2013} & LM33 & DSO & $721.81^{\text {ta }}$ & $1.41^{\mathrm{a}}$ & $70.15^{\mathrm{a}}$ & $11.28^{\mathrm{a}}$ & $3.98^{\mathrm{a}}$ \\
\hline & & DS10 & $710.95^{\mathrm{ab}}$ & $1.39^{a}$ & $70.08^{a}$ & $11.32^{\mathrm{a}}$ & $3.98^{a}$ \\
\hline & & DS20 & $692.16^{b}$ & $1.34^{\mathrm{b}}$ & $69.81^{\mathrm{a}}$ & $11.40^{\mathrm{a}}$ & $3.98^{\mathrm{a}}$ \\
\hline & ZD958 & DSO & $750.32^{a}$ & $1.29^{a}$ & $73.15^{\mathrm{a}}$ & $8.23^{a}$ & $3.98^{a}$ \\
\hline & & DS10 & $736.76^{b}$ & $1.26^{\mathrm{a}}$ & $72.50^{\mathrm{a}}$ & $8.38^{a}$ & $3.98^{\mathrm{a}}$ \\
\hline & & DS20 & $720.11^{c}$ & $1.18^{b}$ & $71.57^{\mathrm{a}}$ & $8.42^{\mathrm{a}}$ & $3.98^{\mathrm{a}}$ \\
\hline \multirow[t]{6}{*}{2014} & LM33 & DSO & $715.03^{a}$ & $1.35^{\mathrm{a}}$ & $70.03^{a}$ & $11.21^{\mathrm{a}}$ & $4.24^{\mathrm{a}}$ \\
\hline & & DS10 & $696.55^{b}$ & $1.33^{\mathrm{a}}$ & $69.96^{\mathrm{a}}$ & $11.32^{\mathrm{a}}$ & $4.18^{a}$ \\
\hline & & DS20 & $679.46^{c}$ & $1.24^{\mathrm{b}}$ & $69.60^{\mathrm{a}}$ & $11.40^{\mathrm{a}}$ & $4.09^{a}$ \\
\hline & ZD958 & DSO & $740.26^{a}$ & $1.29^{a}$ & $72.12^{\mathrm{a}}$ & $8.19^{a}$ & $4.11^{\mathrm{a}}$ \\
\hline & & DS10 & $724.02^{b}$ & $1.27^{\mathrm{a}}$ & $71.75^{\mathrm{a}}$ & $8.25^{a}$ & $4.03^{\mathrm{a}}$ \\
\hline & & DS20 & $712.78 b$ & $1.21 b$ & $70.68 a$ & $8.37 a$ & 3.91a \\
\hline \multicolumn{8}{|c|}{ Source of variation } \\
\hline \multicolumn{3}{|c|}{ Delayed sowing (DS) } & * & * & ns & ns & ns \\
\hline \multicolumn{3}{|c|}{ Genotype (G) } & $\star *$ & * & * & * & * \\
\hline \multicolumn{3}{|c|}{$D S \times G$} & ns & * & ns & ns & ns \\
\hline
\end{tabular}

Different small letters represents statistically significant differences at the $P<0.05$ level by Duncan's test. DS0, DS10 and DS20 were indicated seed planting delayed 0,10 , and 20 days from normal planting time, respectively. ${ }^{\star} P<0.05 ;{ }^{\star \star} P<0.01$; ns, not significant.

Table 5: Correlation analysis for grain yield, yield components and quality traits of treatments

\begin{tabular}{|c|c|c|c|c|c|c|c|c|c|c|c|c|}
\hline & $\begin{array}{l}\text { Grain } \\
\text { Yield }\end{array}$ & Biomass & BMA & BMP & BMR & TKW & KNPS & GTW & $\begin{array}{c}\mathrm{N} \\
\text { content }\end{array}$ & $\begin{array}{l}\text { Starch } \\
\text { content }\end{array}$ & $\begin{array}{c}\text { Oil } \\
\text { content }\end{array}$ & $\begin{array}{l}\text { Protein } \\
\text { content }\end{array}$ \\
\hline $\begin{array}{l}\text { Grain } \\
\text { Yield }\end{array}$ & 1.00 & & & & & & & & & & & \\
\hline Biomass & $0.862^{\star \star}$ & 1 & & & & & & & & & & \\
\hline BMA & 0.542 & $0.852^{\star *}$ & 1.00 & & & & & & & & & \\
\hline BMP & $0.755^{\star \star}$ & $0.802^{\star *}$ & $0.637^{*}$ & 1.00 & & & & & & & & \\
\hline BMR & 0.5011 & 0.138 & $0.855^{\star *}$ & -0.480 & 1 & & & & & & & \\
\hline TKW & $0.736^{\star *}$ & $0.753^{\star *}$ & $0.614^{*}$ & 0.361 & 0.508 & 1.00 & & & & & & \\
\hline KNPS & $0.664^{*}$ & $0.616^{*}$ & $0.786^{\star *}$ & 0.388 & 0.258 & $0.790^{* *}$ & 1.00 & & & & & \\
\hline GTW & $0.701^{*}$ & $0.835^{\star \star}$ & 0.453 & $0.584^{*}$ & 0.258 & 0.504 & 0.162 & 1 & & 1 & & \\
\hline $\mathrm{N}$ content & 0.219 & 0.112 & 0.503 & -0.316 & $0.689^{*}$ & $0.641^{*}$ & -0.450 & -0.066 & 1 & & 1 & \\
\hline $\begin{array}{l}\text { Starch } \\
\text { content }\end{array}$ & 0.327 & $0.732^{*}$ & 0.563 & 0.752 & -0.127 & -0.219 & -0.029 & $0.889^{* *}$ & -0.405 & 1.00 & & 1 \\
\hline Oil content & 0.248 & 0.226 & 0.563 & -0.241 & $0.731^{* *}$ & $0.771^{* *}$ & $0.669^{*}$ & 0.006 & $0.899^{*}$ & -0.323 & 1.00 & \\
\hline $\begin{array}{l}\text { Protein } \\
\text { content }\end{array}$ & -0.347 & -0.364 & -0.185 & -0.563 & 0.293 & 0.145 & 0.387 & $-0.739^{\star *}$ & $0.670^{\star}$ & $-0.855^{\star \star}$ & $0.648^{*}$ & 1.00 \\
\hline
\end{tabular}

$\mathrm{BMA}=$ biomass at anthesis, BMP=biomass at post-anthesis, BMR=biomass remobilization amount during grain filling, TKW=thousand kernel weight, KNPS=kernel number per square, GTW=grain test weight. ${ }^{*} P<0.05 ;{ }^{\star \star} P<0.01$.

time can directly or indirectly affect crop grain yield by influencing biomass accumulation, dry matter translocation or yield components. In general, plants in ear sowing tend to have taller plants, more leaves numbers of higher leaf area index (LAI), and consequently leading to a higher biomass in maturity (Verma et al., 2012). In turn, delayed planting date can result in decrease biomass and yield loss, due to shorter duration of vegetative and grain filling period (Sanchez et al., 2014). The similar results were confirmed in this study, maize grain yield with delayed sowing of DS10 and DS20 treatments had a reduction trend combined with both varieties, whereas no significant difference of grain yield was found between DS0 and DS10. This result is in agreement with the previous study of Jaliya et al., (2008) in
Nigeria. Maize grain yield were also significantly $(P<0.01)$ affected by maize genotypes $(G)$, variety ZD958 had higher grain yield and lower yield loss in two consecutive years, that is mainly due to low temperature during grain filling may be detrimental to protein synthesis (Ahmed and Fayyazul, 2015), thus resulting in higher yield reduction of high protein type LM33. These results indicated higher starch genotype maize could obtain higher yield than higher protein genotype maize with delayed sowing date. Therefore, maize grain yield loss caused by late sowing can be alleviated through by strategies of cultivar adjustment.

It has been well-known that maize grain accumulation could be explained by post-silking biomass and/or remobilization 
Cao, et al.

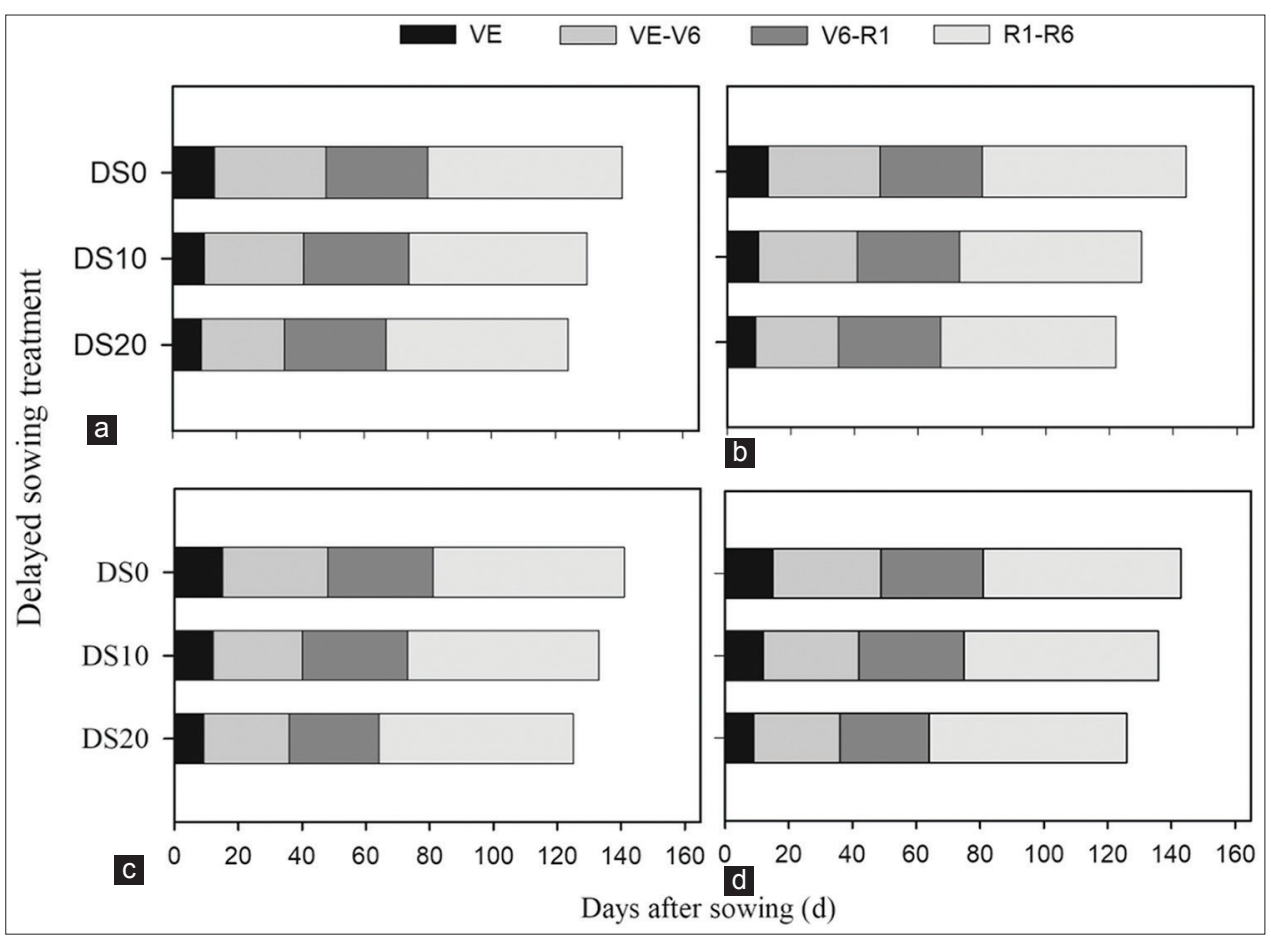

Fig 4. Durations of maize genotype LM33 in 2013(A) and 2014(B), Zd958 in 2013(C) and 2014 (D) as influenced by sowing date. VE: emergency stage; V6: sixth leaf (elongation stage), R1: silking stage; and R6, physiological stages. DS0, DS10 and DS20 were indicated seed planting delayed 0,10 , and 20 days from normal planting time, respectively.

of biomass stored in the stem and leaf during vegetative growth (Ning et al., 2013; Cao et al., 2017). Plant with delayed sowing shortened the growth periods of vegetative and reproductive growth, thus leading to a reduction of dry matter accumulation during growth stage. Significant differences of biomass at anthesis (BMA), post-anthesis (BMP) and remobilization amount (BMR) was observed with delayed sowing date in this study. And the correlation analysis between grain yield and biomass at post-anthesis (BMP) further indicated maize grain yield loss with delayed sowing could be contributed to the decrease of biomass accumulation during post-silking stage. Our results were consistent with Pal, Mahajan et al. (Pal et al., 2017) findings, who confirmed grain yield had a positive relationship with preanthesis dry matter accumulation and dry matter translocations in rice plants in the late sown conditions.

Kernels number per unit and TKW are the main factors influencing grain yield and commodity quality. Reduction of kernel weight by delayed planting could be attributed mainly to decreasing interception of solar radiation and photosynthesis under lower temperatures during grain filling stage, leading to decrease of grain filling rate and duration period (Hu and Wiatrak, 2012), which resulted in lower TKW with later sowing. In this study, kernel numbers per unit and TKW were found significantly affected by DS and maize genotype. Maize LM33 had more kernels number per square than ZD958, but had a lower TKW in yield components because variety LM33 had a smaller kernel size. Reduce of kernels number per unit of both varieties with delayed sowing mainly due to the increase of blank-stem rate (data not showed). Correlation analysis with yield and yield components showed grain yield with delayed sowing mainly influenced by TKW, then followed by kernel numbers. The results were consistent with previous studies of (Lawogbomo and Remison, 2009) together with (Ray and Ahmed, 2019) in maize.

\section{Grain starch, protein, oil content and yield}

Seed quality is important for human and animal food consumption. As known, maize grain nutrients concentration is not only varied between crop genotypes but susceptible affected by agronomic practices and growth environment as well ( $\mathrm{Li}$ et al., 2015; Li et al., 2018). In present study, significant differences $(P<0.01)$ of maize grain starch, protein, and oil content were observed among maize genotypes $(\mathrm{G})$, maize cultivar LM33 had significant higher protein and oil concentration than hybrids ZD958, but opposite to starch content. In addition, the concentration of grain starch and oil were decreased with delayed planting date, and slight increase of protein content were found although the differences were not significant $(P>0.05)$ between DS treatments. This result is in agreement with earlier reports of Ceyhan et al. (2008) in bean (Phaseolus vulgaris L.) and Fabijanac et al. (2006), who demonstrated sowing date did not affect grain yield and protein content in any of the tested hybrids. Similar results of higher protein concentration with late 
sown was also confirmed in wheat and other crop under delayed sowing time (Nielsen et al. 2002; Coventry et al., 2011). The changing of grain protein might be due to the modifications of thermal conditions during grain filling caused by different sowing date (Ahmed and Fayyazul, 2015), which a cool temperature in grain filling stage is beneficial for protein accumulation not starch or oil (Darby and Lauer, 2002).

The nutrient yield is defined as the product of grain yield and nutrient content. Thus, nutrient yield of crops is closely related to the grain yield and nutrient content.

In this study, significant reduction of maize grain starch, protein and oil yield by DS were observed, this is due to delayed sowing significantly decreased maize grain yield while had no significant effect on grain nutrient content. Maize variety ZD958 had a high yield potential, grain starch content and low protein content, leading to a higher starch yield of ZD958, compared to LM33. For different maize genotypes, ZD958 had a higher grain starch yield and lower protein yield across two years average, while no difference of oil yield was found between two maize genotypes. These results suggest we could select suitable varieties according to the purpose of production (for high grain yield or specific nutrition yield) under delayed sowing in framer's agronomy practice.

\section{Grain test weight and $\mathbf{N}$ content}

Grain test weight, associated with kernel size, shape, moisture content and internal structure, is one of the important indexes to estimate grain quality (Cabral et al., 2018). As known, genetic diversity and environmental variability for test weight are present, and the highprotein or oil maize genotypes generally have lower grain test weight than ordinary cultivars (Oikeh et al., 1998; Abbas et al., 2013; Li et al., 2018). In this study, variety ZD958 with higher seed starch concentration and grain test weight was observed. Compared with the normal sowing plants, maize grain test weight in treatment of DS20 was observed in consecutive two years. This might be due to the early sown maize had a long time to utilize light and heat resources for photosynthetic carbon assimilation and seed sink development (Jaliya et al., 2008). Moreover, delayed planting date had a greater effect on maize genotype LM33 in present study, this might be owing to lower temperature in grain filling stage is not conducive to the synthesis of protein and seed formation.

Nitrogen $(\mathrm{N})$ content in seed grains is an important nutrition factor, which is highly associated with human health and animal feeding (Cao et al., 2017). It has been well-known that grain $\mathrm{N}$ accumulation is not only based on $\mathrm{N}$ uptake during the post-silking stage, but also closely related to the remobilization of $\mathrm{N}$ stored in leaf and stem during vegetative growth stage (Liu et al., 2016). It was found that the grain $\mathrm{N}$ concentration was significantly reduced of both maize genotypes under delayed planting date. This can be attributed to the delayed sowing time decreased vegetative growth duration, resulting in the decrease of $\mathrm{N}$ absorption in critical period of nitrogen uptake in vegetative growth stage. In addition, grain $\mathrm{N}$ content was significantly affected by corn genotypes and the interaction of DS and genotypes $(\mathrm{DS} \times \mathrm{G})$, due to $\mathrm{N}$ uptake and remobilization in crops had specific genetic variability (Oikeh et al., 1998).It has been well documented that there is a positive correlation between protein concentration and $\mathrm{N}$ content in crop seeds. However, the seed protein concentration was not consist with $\mathrm{N}$ content in present study, one of the possible reason for explain the increase of protein concentration might be due to delayed planting date enhanced the rate of $\mathrm{N}$ remobilization (Hu and Wiatrak, 2012), and result in the reduction of $\mathrm{N}$ content.

\section{CONCLUSION}

Delayed sowing date had significant impacts on the timing of key phenological period, shortened maize vegetative growth and total growth duration time in fainfed conditions of NCP. Maize grain yield, biomass, yield components (kernel number per square and TKW), grain nutrition yield, $\mathrm{N}$ concentration and grain test weight were significantly reduced by DS. Therefore, early sowing should be recommended to the framers. Compared to high protein maize genotype LM33, high starch maize genotype ZD958 had a higher yield potential and lower yield reduction with delayed sowing. Grain yield loss under DS could be mainly attributed to reduction of the BMP and biomass, thereby leading to the reduction of TKW and kernels number per unit. DS didn't affected grain nutritional content (starch, protein and oil), while significantly reduced grain nutrition yield of starch and protein with delayed sowing. These results suggested that varieties adjustments maybe a possible approach to reduce and compensate for the loss of yield caused by delayed sowing in rain-fed condition under climate change in NCP.

\section{ACKNOWLEGMENTS}

This work was granted financial support from the Ministry of Science and Technology of the People's Republic of China (2018YFD0300202), China Postdoctoral Science Foundation (2017M621228), and Agricultural Science and Technology Innovation funds for Jilin province of China (CXGC2017TD011and C7208000101). 


\section{Author's contributions}

All authors contributed extensively to the work presented in this manuscript. Q. C. wrote the article and corrected it. G. L. designed and performed research and revised the manuscript. F.Y., X.C., Q. C., L. D., E.Z., and F. K. participated in experiments and conducted the experimental work. All authors read and approved the final manuscript.

\section{REFERENCE}

Abbas, G., M. Saqib, Q. Rafique, M. A. U. Rahman, J. Akhtar, M. A. U. Haq and M. Nasim. 2013. Effect of salinity on grain yield and grain quality of wheat (Triticum aestivum L.). Pak. J. Agric. Res. 50: 185-189.

Abdelkader, A. 2018. Physiological and chemical characteristics of cultivated single cross maize (Zea mays L.) hybrids. Egypt. J. Exp. Biol. 14(1): 19-27.

Ahmed, M. and H. Fayyaz. 2015. Response of spring wheat (Triticum aestivum L.) quality traits and yield to sowing date. PLoS One. 10: e126097.

Bajaj, S., P. Chen, D. E. Longer, A. Hou, A. Shi, T. Ishibashi, B. Zhang and K. R. Brye. 2008. Planting date and irrigation effects on seed quality of early-maturing soybean in the Mid-South USA. J. New Seeds. 9: 212-233.

Cabral, A. L., M. C. Jordan, G. Larson, D. J. Somers, D. G. Humphreys and C. A. McCartney. 2018. Relationship between QTL for grain shape, grain weight, test weight, milling yield, and plant height in the spring wheat cross RL4452/"AC Domain". PLoS One. 13: e190681.

Cao, Q. J., G. Li, F. T. Yang, X. L. Jiang, L. Diallo and F. X. Chen. 2017. Plough pan impacts maize grain yield, carbon assimilation, and nitrogen uptake in the corn belt of northeast China. Emirates J. Food Agric. 29(7): 502-508.

Ceyhan, E., M. Harmankaya and M. A. Avci. 2008. Effects of sowing dates and cultivars on protein and mineral contents of bean (Phaseolus vulgaris L.). Asian J. Chem. 20: 5601-5613.

Chen, X., F. Chen, Y. Chen, Q. Gao, X. Yang, L. Yuan, F. Zhang and G. Mi. 2013. Modern maize hybrids in Northeast China exhibit increased yield potential and resource use efficiency despite adverse climate change. Glob. Change Biol. 19: 923-936.

Costabr, R., N. Pinheiro, A. Almeida, C. Gomes, J. Coutinho, J. Coco and A. Costa. 2013. Effect of sowing date and seeding rate on bread wheat yield and test weight under Mediterranean conditions. Emirates J. Food Agric. 25(12): 951-956.

Coventry, D. R., R. K. Gupta, A. Yadav, R. S. Poswal, R. S. Chhokar, R. K. Sharma, V. K. Yadav, S. C. Gill, A. Kumar and A. Mehta. 2011. Wheat quality and productivity as affected by varieties and sowing time in Haryana, India. Field Crops Res. 123: 214-225.

Darby, H. M. and J. G. Lauer. 2002. Planting date and hybrid influence on corn forage yield and quality. Agron. J. 94: 281-289.

Fabijanac, D., B. Varga, Z. Svecnjak and D. Grbesa. 2006. Grain yield and quality of semiflint maize hybrids at two sowing dates. Agric. Conspectus Sci. 71: 45-50.

Gaile, Z. 2012. Maize (Zea mays L.) response to sowing timing under agro-climatic conditions of Latvia. Žemdirbystè. 99: 31-40.

Guanming, S., C. Jean-Paul and L. Joseph. 2013. Commercialized transgenic traits, maize productivity and yield risk. Nat. Biotechnol. 31: 111-114.

Guo, J. M., J. Q. Xue, A. D. Blaylock, Z. L. Cui and X. P. Chen, 2017. Film-mulched maize production: Response to controlled-release urea fertilization. J. Agric. Sci. 155: 1299-1310.

$\mathrm{Hu}, \mathrm{M}$. and P. Wiatrak. 2012. Effect of planting date on soybean growth, yield, and grain quality: Review. Agron. J. 104: 785.

Jaliya, M. M., A. M. Falaki, M. Mahmud and Y. A. Sani. 2008. Effect of sowing date and NPK fertilizer on yield and yield components of quality protein in maize (Zea mays L.). ARPN J. Agric. Biol. Sci. 3(2): 23-29.

Lawogbomo, K. E. and S. U. Remison. 2009. Growth and yield of maize as influenced by sowing date and poultry manure application. Notulae Bot. Horti Agrobot. Cluj-Napoca. 37: 199-203.

Li, C., Y. Huang, R. Huang, Y. Wu and W. Wang. 2018. The genetic architecture of amylose biosynthesis in maize kernel. Plant Biotechnol. J. 16: 688-695.

Li, H., J. L. Lindquist and Y. Yang. 2015. Effects of sowing date on phenotypic plasticity of fitness-related traits in two annual weeds on the Songnen Plain of China. PLoS One. 10: e127795.

Li, H., Q. Yang, N. Fan, M. Zhang, H. Zhai, Z. Ni and Y. Zhang. 2017. Quantitative trait locus analysis of heterosis for plant height and ear height in an elite maize hybrid zhengdan 958 by design III. BMC Genet. 18: 36.

Liu, Z., A. Qin, B. Zhao, S. T. Ata-Ul-Karim, J. Xiao, J. Sun, D. Ning, Z. Liu, J. Nan and A. Duan. 2016. Yield response of spring maize to inter-row subsoiling and soil water deficit in Northern China. PLoS One. 11: e153809.

Liu, Z., X. Yang, X. Lin, P. Gowda, S. Lv and J. Wang. 2018. Climate zones determine where substantial increases of maize yields can be attained in Northeast China. Clim. Change. 149: 473-487.

Luo, Q., G. O'Leary, J. Cleverly and D. Eamus. 2018. Effectiveness of time of sowing and cultivar choice for managing climate change: Wheat crop phenology and water use efficiency. Int. J. Biometeorol. 62: 1049-1061.

Mason, S. C. and N. E. D'Croz-Mason. 2008. Agronomic practices influence maize grain quality. J. Crop Prod. 5: 75-91.

Nielsen, R. L., P. R. Thomison, G. A. Brown, A. L. Halter, J. Wells and K. L. Wuethrich. 2002. Delayed planting effects on flowering and grain maturation of dent corn. Agron. J. 94: 549-558.

Ning, P., S. Li, P. Yu, Y. Zhang and C. Li. 2013. Post-silking accumulation and partitioning of dry matter, nitrogen, phosphorus and potassium in maize varieties differing in leaf longevity. Field Crops Res. 144: 19-27.

Oikeh, S. O., J. G. Kling and A. E. Okoruwa.1998. Nitrogen fertilizer management effects on maize grain quality in the West African moist Savanna. Crop Sci. 38: 1056-1161.

Ozturk, A., O. Caglar and S. Bulut. 2010. Growth and yield response of facultative wheat to winter sowing, freezing sowing and spring sowing at different seeding rates. J. Agron. Crop Sci. 192: 10-16.

Pal, R., G. Mahajan, V. Sardana and B. S. Chauhan. 2017. Impact of sowing date on yield, dry matter and nitrogen accumulation, and nitrogen translocation in dry-seeded rice in North-West India. Field Crops Res. 206: 138-148.

Ray, J. and J. Ahmed. 2019. Grain growth and yield potential of wheat genotypes under late sown heat stressed condition. Fundam. Appl. Agric. 4(1): 671-679.

Sanchez, B., A. Rasmussen and J. R. Porter. 2014. Temperatures and the growth and development of maize and rice: A review. Glob. Change Biol. 20: 408-417.

Shah, M. A., M. Farooq, M. Shahzad and M. Hussain. 2017. Yield and phenological responses of BT cotton to different sowing dates in semi-arid climate. Pak. J. Agric. Sci. 54: 233-239.

Shaik, S. S., M. Carciofi, H. J. Martens, K. H. Hebelstrup and A. Blennow. 2014. Starch bioengineering affects cereal grain germination and 
seedling establishment. J. Exp. Bot. 65: 2257-2270.

Tao, F., S. Zhang, Z. Zhang and R. P. Rotter. 2014. Maize growing duration was prolonged across China in the past three decades under the combined effects of temperature, agronomic management, and cultivar shift. Glob. Change Biol. 20: 3686-3699.

Van Roekel, R. J. and J. A. Coulter. 2011. Agronomic responses of corn to planting date and plant density. Agron. J. 103: 1414.

Verma, N. K., B. K. Pandey, U. P. Singh and M. D. Lodhi. 2012. Effect of sowing dates in relation to integrated nitrogen management on growth, yield and quality of rabi maize (Zea mays L.). J. Anim. Plant Sci. 22: 249-249.
Wang, X., D. Cai, Q. Zhao, X. Xie, W. B. Hoogmoed and O. Oenema. 2018. Balanced $N$ and $C$ input recommendations for rain-fed maize production in northern China based on $\mathrm{N}$ balances and grain yields. J. Sci. Food Agric. 98: 872-883.

Yan, D., L. Duermeyer, C. Leoveanu and E. Nambara. 2014. The functions of the endosperm during seed germination. Plant Cell Physiol. 55: 1521-1533.

Zhao, C., W. Xu, X. Song, W. Dai, L. Dai, Z. Zhang and S. Qiang. 2018. Early flowering and rapid grain filling determine early maturity and escape from harvesting in weedy rice. Pest Manag. Sci. 74: 465-476. 